\title{
25 Research Square \\ Sustainable Development Goal 13 and Switching \\ Priorities: Addressing Climate Change in the Context of Pandemic Recovery Efforts
}

\author{
Walter Leal Filho \\ Hamburg University of Applied Sciences \\ Aprajita Minhas ( $\sim$ Aprajita.minhas@gmail.com ) \\ Hamburg University of Applied Sciences \\ Birgit Schmook \\ El Colegio de la Frontera Sur
}

\section{Sofia Mardero}

University of St Andrews

\section{Ayyoob Sharifi}

Hiroshima University

\section{Shlomit Paz}

University of Haifa

\section{Marina Kovaleva}

Hamburg University of Applied Sciences

Maria Cristina Albertini

University of Urbino Carlo Bo

\section{Antonis Skouloudis}

University of the Aegean

\section{Research Article}

Keywords: COVID-19, SDG13, Climate change, Climate finance, and Poverty

Posted Date: March 1st, 2022

DOI: https://doi.org/10.21203/rs.3.rs-1366971/v1

License: (c) (i) This work is licensed under a Creative Commons Attribution 4.0 International License. Read Full License 


\section{Abstract}

The COVID-19 pandemic has had many deep social and economic impacts that go beyond health issues. One consequence is that the pandemic has made it even harder to mobilize the financial resources needed to pursue SDG 13 (Climate Action) as a whole and to fund climate change mitigation and adaptation efforts in particular. This is especially acute in respect of the efforts to achieve the targets set by the Paris Agreement and by the recent decisions in Glasgow. This paper looks at how the COVID-19 pandemic has accelerated poverty and undermined climate change adaptation efforts, as a result of the switches in priorities and funding. Using a review of the recent literature, an analysis of international trends, and a survey among climate scientists, it identifies some of the impacts of the pandemic on climate change mitigation and adaptation efforts and discusses their implications. The findings indicate a decrease in funding to climate change research since the pandemic crisis. The bibliometric analysis reveals that a greater emphasis has been placed on the relationship between COVID-19 and poverty when compared to the interrelations between COVID-19 and climate change. Addressing climate change is as urgent now as it was since the pandemic crisis started, and efforts need to be made to upkeep the levels of funding needed to support research in this field.

\section{Introduction: The Covid-19 Pandemic And Its Socio-economic}

Since the onset of the pandemic, many researchers have worked hard to understand the pathogenetic mechanisms responsible for the development of COVID-19 disease. Understanding the SARS-CoV-2 underlying the infection allows the scientific community to activate therapeutic strategies to counter the pandemic that is advancing dramatically. In fact, to date, the number of infected people and deaths continues to rise (1). Unfortunately, the COVID-19 infectious process presents still unknown aspects that prevent the use of effective therapies (2). For this reason, preventing the entry of the virus, for example with the use of vaccines, seems to be one of the best solutions to keep the pandemic under control. However, while waiting to achieve vaccination-mediated herd immunity, another effective containment measure is associated with social distancing and lockdowns (3). Although COVID-19-related restrictions have led to a sudden reduction in greenhouse gas (GHG) emissions and air pollutants, this brief spell will have a modest impact on the crisis according to a new study (4). However, a post-lockdown economic recovery plan that includes and underlines an environmentally friendly future could make a significant contribution to the fight against global warming. Researchers (4) say the world has a good chance of limiting global warming if governments choose rigid green policies and investments that restore economies following the coronavirus pandemic.

There are comparable aspects between the COVID-19 crisis and what we expect from the imminent global climate emergency. Some researchers reflected upon the challenges of today's crisis and compiled a list of the similarities and differences between the two crises:
i. High impact trends, with worldwide implications
ii. Some of the changes caused by them may be irreversible
iii. Exacerbate social inequalities,
iv. Weakening of international solidarity, and
v. Less costly to prevent than to cure (5).

These similarities will have to be taken into consideration to trigger new actions to solve both crises at the same time. In comparison to the COVID-19 crisis, the climate crisis has a slower temporal dimension. Changes in large- 
scale climate patterns can initiate irreversible processes with unpredictable negative consequences (5). The richest countries can invest in prevention rebuilding of the climate change impacts and while less developed nations may suffer increasing inequalities. While Global warming would cause competition for resources increasing mass migration (5).

The pandemic has affected all areas (6), and among the primary sectors, the agricultural industry has been heavily affected (7). This was mostly seen through the reduced number of staff available to work, which lowered the levels of trade of some agricultural commodities (e.g., fruits, flowers) in the earlier stages of the pandemic. In other instances, panic buying of food and other basic ingredients led to an increase in demand during the beginning of the first wave; the supply remained limited, causing temporary disarray in the industry (8), which has since stabilized. Furthermore, in the beginning, the primary healthcare services were affected by the shortage of equipment and funds to purchase medical resources. Moreover, in developing countries, a lack of medical resources and PPE was observed and is still the case, due to the existing inadequate funding (9).

The manufacturing industry (secondary sector) was also impacted by the pandemic. Levels of international trade were reduced at the beginning of the pandemic, which prevented many products from being manufactured due to a shortage of the necessary materials. The reduction in the levels of manufacturing of goods placed a significant strain on the economies of many countries, thus causing reductions in the gross domestic products of many affected nations $(8,10)$.

The education sector, at all levels, was one of the most affected. The limited ability to have normal classes and the sudden shifting to online platforms has placed a significant strain on students and learners (11). Furthermore, the reductions in the volume of air travel have increased the financial strains on this industry (12). This has, in turn, severely damaged the tourism sector of most countries and caused adverse effects to their economies (13).

Social issues that arose from the pandemic also include increased poverty, mental health issues, inequalities towards vulnerable groups, and gender-based violence. The loss of employment of a large percentage of individuals placed many families below the poverty line (14). Furthermore, people who engage in informal trade saw significant reductions in their income, whereas some received no income at all for a long period, further worsening poverty (15). Figure 1 presents an overview of the domino effect caused by the pandemic.

A further socio-economic impact is seen in the overall field of health. Apart from the millions of people infected and the clinical cases associated with it, the financial stress triggered by the pandemic caused many people to experience mental health problems such as anxiety or depression (16). In particular, the loss of family members to the virus and the economic uncertainties caused by the pandemic led to the initiation or worsening of already existing mental health conditions (17). In other instances, social isolation and staying home for long periods have been associated with increases in violence in households, especially against women (18).

While the COVID-19 pandemic had impacts on finance resources worldwide, this paper looks at how it has accelerated poverty and undermined climate change adaptation efforts, as a result of the switches in priorities and funding.

\section{Climate Change And The Covid-19 Pandemic}

The COVID-19 pandemic has led to both global health and economic impacts at the same time, which shows resemblance with the climate crisis (19). The COVID-19 pandemic has disclosed the fragility of health care, social 
systems, and the economy (20). In a world of irreversible impacts from climate change, the disordering of the global supply chain due to the pandemic has led to a loss of approximately 495 million full-time-equivalent jobs, especially low-paid jobs (21). According to the IMF (International Monetary Fund), in the year 2020, it was predicted that the Global GDP would contract by $4.9 \%$ in 2020 and by $6.5 \%$ in 2021 when compared to the pre-pandemic projections (22), which is greater than the 2008-2009 global financial crisis. At the same time, the European Commission expects a greater reduction of 7.5\% for the European Union (23). COVID-19 and climate change are currently the subject of policy debates, with the goal of reducing economic loss through implementing clean recovery stimulus packages (e.g., Hepburn et al., 2020; Gawel and Lehmann, 2020) (24, 25). The COVID-19 crisis has seriously damaged public finances. It is hard to finance recovery and initiate critical investments for climate adaptation and mitigation. However, a delay in climate action might even result in a higher cost $(22,26,27)$. Developing countries are further limited in access to climate finance investments because of the following: (28)

- A sudden drop in domestic public revenues and decline in sovereign credit ratings

- Recession of private external funding

- Solvency and liquidity crisis for SMEs (Small and Medium Enterprises).

Moreover, debt relief will be needed by many countries to counter the crisis and will require investments to climateproof the economies.

Even before the pandemic, both the private and public sectors were struggling with how to achieve the goal of $\$ 100$ billion in annual funding to assist low-income nations in combating climate change through adaptation and mitigation measures. (27). Nevertheless, OECD nations' climate finance contributions have increased in recent years, from USD 58.6 billion in 2016 to USD 78.9 billion in 2018, showing a favourable trend toward achieving the target.

(Fig. 2. Climate finance provided and mobilized [2013-18, USD billion])

About USD 2.4 trillion would need to be invested annually in the energy sector from 2016 to 2035 to stay on a 1.5degree Celsius pathway (30). It was estimated that reaching zero energy-related emissions by 2050 requires an annual global expenditure of USD 1.6 trillion in renewables, electric vehicles, hydrogen, carbon capture, and biofuels technologies (31). In 2019, the global public and private climate finances that include, among others, flows from financial institutions, governments, companies, and households (32), reached about USD 608-622 billion, which was approximately $15 \%$ higher than the amount generated in 2018 (33). However, this level of financing will not be sufficient for the low-carbon transition between 2016-2050 and to cover the costs of adaptation between 2020-30 (34). The COVID-19 pandemic, recovery actions, and the post-crisis economic situation might undermine wealthy nations' priorities and abilities to provide climate finance $(29,35)$ and alter their green plans, as in the case of China (36). The national lockdowns are expected to reduce investments in renewable energy projects in 2020 by $10 \%$ compared to 2019 (37), though this value will vary with the lockdown's severity (33). To support economic activities, national governments have introduced a set of stimulus packages that include tax cuts and tax reliefs, benefit payments, grants, and business loans. Currently, the total amount of stimulus has reached USD 12.7 trillion and continues to grow with the introduction of new economic measures (38). According to the Greenness of Stimulus Index (GSI), 15 of the announced packages by the $\mathrm{G} 20$ will lead to an additional environmental impact or reinforce existing damages (38) by supporting sectors that heavily affect climate change and biodiversity and increase pollution. Firms from the carbon-intensive sectors, the majority of which are in Asia, already received USD 866 billion as part of the earlier stimulus programs (33). Moreover, only 12 of the 300 policies have been implemented, as part of the USD 7.3 trillion stimulus package approved by the G20 nations in April 2020 to reduce long-term CO2 emissions (24). The ongoing introduction of stimulus measures is seen by experts as an opportunity for national 
governments to support the decarbonization of their economies by prioritizing such areas as clean energy and physical infrastructure, education and training, natural capital, the energy efficiency of buildings (24) by eliminating subsidies for fossil-fuel, and pricing pollution and carbon (39). Stimulus packages released by major economies include climate change-related measures that differ in types and dimensions. The share of the budget assigned for these purposes and implementation frames is not always stated clearly. Moreover, the earlier packages provided short-term support for heavily affected areas, including the carbon-intensive industries. Examples of some 'green' and 'brown' measures adopted in stimulus packages of the selected major economies are presented in Table 1 (Examples of 'green' and 'brown' introduced). Currently, the European Commission has introduced a stimulus package with the most ambitious support of climate-related actions (40). 
Table 1

Examples of 'green' and 'brown' measures introduced in recovery packages of the selected economies

\begin{tabular}{|c|c|c|c|c|}
\hline \multirow[t]{2}{*}{ Recovery package } & \multirow[t]{2}{*}{ Country } & \multicolumn{2}{|l|}{ Green measures } & \multirow[t]{2}{*}{ References } \\
\hline & & YES & NO & \\
\hline \multirow[t]{4}{*}{$\begin{array}{l}\text { Approx. USD } 510 \text { billion relief } \\
\text { packages }\end{array}$} & \multirow[t]{4}{*}{ China } & $\begin{array}{l}\text { - No strong focus on } \\
\text { construction projects that } \\
\text { could lead to a spike of CO2 } \\
\text { emissions } \\
\text { - Construction of additional } \\
\text { battery-charging and } \\
\text { swapping facilities }\end{array}$ & $\begin{array}{l}\text { - Investments in } \\
\text { the fossil fuel } \\
\text { sectors } \\
\text { - Cancellation of } \\
\text { civil aviation } \\
\text { development fund } \\
\text { contributions }\end{array}$ & \multirow[t]{4}{*}{36,41} \\
\hline & & $\begin{array}{l}\text { - Promotion of wider use of } \\
\text { electric and other clean } \\
\text { energy automobiles. } \\
\text { - Promotion of cleaner and } \\
\text { more efficient use of coal }\end{array}$ & \multirow[t]{3}{*}{$\begin{array}{l}\text { - Reduction of } \\
\text { electricity prices } \\
\text { for general } \\
\text { industrial and } \\
\text { commercial } \\
\text { businesses }\end{array}$} & \\
\hline & & $\begin{array}{l}\text { - Development of renewable } \\
\text { energy }\end{array}$ & & \\
\hline & & $\begin{array}{l}\text { - Improvement of systems for } \\
\text { the production, supply, and } \\
\text { sale of oil, natural gas, and } \\
\text { electricity }\end{array}$ & & \\
\hline \multirow[t]{4}{*}{$\begin{array}{l}\text { Approx. USD } 2.16 \text { trillion } \\
\text { stimulus package }\end{array}$} & \multirow[t]{4}{*}{$\begin{array}{l}\text { European } \\
\text { Union }\end{array}$} & $\begin{array}{l}\text { - Support of modernization } \\
\text { through policies that include } \\
\text { research and innovation, } \\
\text { among others, via fair } \\
\text { climate transition }\end{array}$ & & \multirow[t]{4}{*}{40} \\
\hline & & $\begin{array}{l}-30 \% \text { of the funds for } \\
\text { combating climate change }\end{array}$ & & \\
\hline & & $\begin{array}{l}\text { - Commitment to propose a } \\
\text { carbon border adjustment } \\
\text { mechanism }\end{array}$ & & \\
\hline & & $\begin{array}{l}\text { - Review of the EU Emissions } \\
\text { Trading System }\end{array}$ & & \\
\hline $\begin{array}{l}\text { USD } 70.5 \text { billion nationwide } \\
\text { economic recovery plan }\end{array}$ & Russia & $\begin{array}{l}\text { One of the main orientations } \\
\text { of the plan is sustainable } \\
\text { economic growth, but the } \\
\text { details have not yet been } \\
\text { made public. }\end{array}$ & $\begin{array}{l}\text { Tax measures, } \\
\text { loans, and } \\
\text { government reliefs } \\
\text { to support } \\
\text { the most affected } \\
\text { by the pandemic } \\
\text { areas, among } \\
\text { which are carbon- } \\
\text { intensive industries }\end{array}$ & 42,43 \\
\hline
\end{tabular}




\begin{tabular}{|c|c|c|c|c|}
\hline Recovery package & Country & Green measures & & References \\
\hline $\begin{array}{l}\text { Almost USD } 4 \text { trillion, } \\
\text { government total support } \\
\text { and } \\
\text { USD } 1.3 \text { trillion as a new } \\
\text { package }\end{array}$ & USA & $\begin{array}{l}\text { - Significant investment in } \\
\text { solar, wind, and energy } \\
\text { storage, grid modernization } \\
\text { - Phase-down of the use of } \\
\text { hydrofluorocarbons } \\
\text { - Weather-proofing of low- } \\
\text { income households } \\
\text { - Expansion of carbon } \\
\text { capture and storage } \\
\text { - Improvement of energy } \\
\text { efficiency of schools and } \\
\text { federal buildings }\end{array}$ & $\begin{array}{l}\text { - USD } 58 \text { billion to } \\
\text { support the } \\
\text { national aviation } \\
\text { industry }\end{array}$ & 44,45 \\
\hline $\begin{array}{l}1.1 \text { trillion USD a fiscal } \\
\text { stimulus package and a new } \\
\text { USD } 708 \text { billion economic } \\
\text { stimulus package }\end{array}$ & Japan & $\begin{array}{l}\text { New package includes } \\
\text { spending and initiatives } \\
\text { aiming to reduce carbon } \\
\text { emissions, including } \\
\text { promotion of carbon } \\
\text { neutrality, by } 2050\end{array}$ & & 47,48 \\
\hline $\begin{array}{l}\text { Approx. USD } 157 \text { billion } \\
\text { stimulus program }\end{array}$ & Germany & $\begin{array}{l}\text { - Promotion of hydrogen } \\
\text { technology } \\
\text { - Grants to reduce the } \\
\text { surcharge levied on electricity } \\
\text { consumers } \\
\text { Increased investment in the } \\
\text { carbon building renovation } \\
\text { program } \\
\text { - A higher target for } \\
\text { expanding offshore wind } \\
\text { power. } \\
\text { - Cancelling of the cap on } \\
\text { solar power expansion }\end{array}$ & & 49 \\
\hline $\begin{array}{l}\text { Up to USD } 27 \text { billion in direct } \\
\text { support to workers and } \\
\text { businesses and up to } \\
\$ 750 \text { million for a new } \\
\text { Emissions Reduction Fund }\end{array}$ & Canada & $\begin{array}{l}\text { New Emissions Reduction } \\
\text { Fund to support workers and } \\
\text { reduce emissions in Canada's } \\
\text { oil and gas sector, with a } \\
\text { focus on methane. }\end{array}$ & & 50 \\
\hline
\end{tabular}

There are also more efforts to foster economic support to countries, as the pandemic enters its 4th wave.

\section{Methodology}

The study employed a quantitative research methodology with the help of a survey and bibliometric analysis. To get expert opinions on how the COVID-19 pandemic has accelerated poverty and undermined climate change adaptation efforts, we posted an online survey. The intended audience for this online survey was scientists, but also government employees, and members of NGOs working on climate change-related topics. The main purpose of the questionnaire was to find out whether funding for climate change-related projects has decreased. For this purpose, we divided the 
questionnaire into 3 sections: a) scientists' background (questions about their country, gender, age, average salary); b) scientists' profile (asking about their professional field, the main country where they carry out their research, etc.); and c) access to climate change research funds (asking if the amount of funding for their research changed since March 2020, among other questions). The link to the questionnaire was spread out by all co-authors to various expert networks in the fields of climate and environmental changes, which, being affiliated with universities and research centers in different parts of the world, such as Germany, the UK, Japan, Mexico, and Israel, allowing for a more global reach. Participation was voluntary and strictly confidential, and this was mentioned to the respondents at the beginning of the survey. The survey was undertaken from 24th February to 7th May 2021.

To gain an overview of the knowledge structure on the interactions between the COVID-19 pandemic, climate change policies, and poverty, we relied on the bibliometric analysis provided by VOS viewer, which is widely used for this purpose (50). Specifically, we used the term co-occurrence analysis, which provides insight into dominant and common themes and key research focus areas. The input data had been resulted from a literature search in the Web of Science. After doing some pre-processing data cleaning to merge synonymous terms, the term co-occurrence analysis was done for a minimum threshold of five terms (i.e., terms that have, cumulatively, been mentioned at least five times in the reviewed articles). The output is presented in the form of nodes and links (see Fig. 5). In Fig. 5, the node size is proportional to the number of times the terms have been used, and link size is proportional to the strength of the connection. Terms that are close to each other in Fig. 5 have co-occurred more frequently.

\section{Results And Discussion}

\subsection{Survey Results}

\subsubsection{Scientist background}

Of the 103 respondents, 63 were males (61\%) and 37 were females (36\%); 3 individuals preferred not to disclose their sex. Researchers from 49 countries participated in our study, with Germany and the United Kingdom being the countries with the highest participation (8 and 7, respectively). The fact that responses were gathered from scientists from nearly 50 countries adds a significant degree of authority to the study, being consistent to identify whether funding provisions for climate change have changed due to the COVID-19 pandemic.

Most of the 103 individuals reside in Europe ( $N=36 / 35.29 \%$ ), followed by individuals from Africa ( $N=34 / 33.33 \%$ ), Asia ( $N=17 / 16.67 \%)$, Latin America ( $N=8 / 7.84 \%)$, and North America $(\mathrm{N}=6 / 5.88 \%)$, with one person ( $0.98 \%)$ from Australia and Oceania as shown in Fig.3. The respondent's geographical distribution seems to be a reflection of the authors' networks, to which the survey link was distributed and considerably underestimates the number of researchers in other world regions, such as North America. The main age group of the respondents was between 4160 years of age, stated by more than half of the participants (51.49\%). Most of the 100 responses indicate possession of a post-graduate degree $(\mathrm{N}=82 / 82 \%)$. As for the monthly salary of the participants, the results range widely, with a large portion of the participants receiving a monthly salary of up to $€ 1000 / 1350$ US\$ (41\%) per month and another $41 \%$ receiving between $€ 2501 / 3400$ US\$ each month. Most of the low-income respondents are located in Africa, whereas the higher income categories are attributed to individuals living in Europe or North America.

\subsubsection{Scientist profile}

The 100 responses to the scientist profile question indicate that they work for different sectors, with the majority ( $\mathrm{N}$ $=64 / 64 \%)$ being employed in public or private universities, followed by 17 persons $(N=17 / 17 \%)$ working in the NGO 
sector. As for their professional fields, many of the 102 respondents consider themselves environmental scientists $(\mathrm{N}=38 / 37.25 \%)$, followed by individuals engaging in social science and humanities $(\mathrm{N}=27 / 26.47 \%)$. Regarding the question about where the research is carried out, a few respondents mentioned that they work in more than one region; therefore, a total of 135 answers were valid. Most of the research is carried out in Africa $(\mathrm{N}=48 / 35.56 \%)$, especially in the Sub-Saharan portion of the continent; the next in frequency is Asia $(N=28 / 20.74 \%)$ followed by Europe ( $N=26 / 19.26 \%)$ and Latin America and the Caribbean $(N=24 / 17.78 \%)$.

Regarding the field of expertise in climate change research, several respondents mentioned more than one field (271 answers). Fields of research (see Table 2) span over a wide range, with climate change adaptation and resilience being the most popular, followed by impacts, mitigation, and vulnerability assessment.

Table 2

Fields of research of participants

\begin{tabular}{|lll|}
\hline Fields of research & Frequency & Percentages \\
\hline CC adaptation and resilience & 56 & 20.66 \\
\hline CC and conservation & 11 & 4.06 \\
\hline CC awareness & 21 & 7.75 \\
\hline CC communication \& action & 23 & 8.49 \\
\hline CC education & 21 & 7.75 \\
\hline CC governance & 2 & 0.74 \\
\hline CC impacts & 42 & 15.50 \\
\hline CC mitigation & 32 & 11.81 \\
\hline CC projections & 5 & 1.85 \\
\hline CC risk/vulnerability assessment & 31 & 11.44 \\
\hline CC sustainable development and smart livelihoods & 27 & 9.96 \\
\hline
\end{tabular}

\subsubsection{Access to climate change research funds}

Regarding the sources of funding throughout the respondent's career, of the 98 individuals who provided an answer, 48 (48.98\%) mentioned national research councils (public funding) as their main support source for research, followed by International/foreign country councils or corporations (15.31\%). Multilateral climate finances are important for another 15 (15.31\%) of the respondents, while the remaining 16 (16.33\%) listed charitable foundations, self-sponsorship, and undisclosed sources.

When asked whether they had applied for funding after the start of the COVID-19 pandemic in March 2020, of the 102 individuals responding to that question, 66 (64.7\%) stated that they did not apply for any funding. Of the 36 respondents who applied for funding, 14 (40\%) reported a successful outcome, 11 (31.43\%) received a negative result, and 10 (28.57\%) do not know yet about the outcome.

The extent to which the amount of funding for their climate change research changed since March 2020 was rated by 100 respondents as follows: 35 (35\%) stated that they don't know; 29 (29\%) experienced a subsequent decrease 
in funding; 29 (29\%) experienced no change, and only 7 (7\%) found themselves in the lucky situation of increased funding.

Regarding information about whether the researcher's usual sources of funding stopped or postponed funding for climate change projects since March 2020, of the 96 individuals answering this question, approximately a third don't know $(\mathrm{N}=34 / 35.4 \%)$, another third $(\mathrm{N}=32 / 33.3 \%)$ stated that their usual funding source stopped or postponed funding, while the remaining third $(\mathrm{N}=30 / 31.3)$ said this did not happen. Ten $(10.64 \%)$ individuals answered that they don't know if they need to change the focus of their research. As to whether COVID-19 has a direct or indirect relevance to the 99 respondent's research agenda, the vast majority $(\mathrm{N}=77 / 77.8)$ answered yes, while $22(22.2 \%)$ stated that COVID-19 is not of any relevance for their ongoing research. Of these 22 respondents who stated that COVID-19 has no direct or indirect relevance for their research agenda, we wanted to see which field of research they work in. We obtained 71 responses, as several respondents mentioned more than one field; the three main orientations of their research are adaptation and resilience (16\%), risk and vulnerability assessments (14\%), and impacts of climate change (13\%). These fields of research are also the most popular among the 103 respondents. We also performed an association analysis between these variables (the relevance of COVID-19 in their research agenda with their field of climate change research) and the result showed that there is no statistically significant association between the two ( $p$-value $=0.63$ ). The future impact of COVID-19 on their climate change research, as expressed by 100 respondents, is expected to increase according to more than half of the respondents ( $N=56 / 56 \%)$, to decrease as stated by 13 (13\%) respondents, while 15 (15\%) expect no change at all, and 16 (16\%) don't know.

\subsubsection{Associations and dependencies}

Taking into account that many of the participants had stated that their funding for climate change projects had changed since the beginning of the COVID-19 pandemic, the next step was to reveal if these changes had any relation with or dependence on other variables, such as the continent where the participants work, their monthly income, their professional field, the orientation of their research, or their funding agencies.

The following graph (Fig. 4) illustrates an apparent relationship between the participant's geographic region (continent) and changes in financing. It can be seen that in Africa the majority of the respondents (41\%) stated that funding has decreased since the COVID-19 pandemic began.

In Europe, on the other hand, the majority (47\%) of the 36 respondents reported no change in funding, $8 \%$ reported an increase, only $8 \%$ reported a decrease, and $36 \%$ did not know.

This may be linked to the Recovery Package of the European Commission, which stated that $30 \%$ of the EU funds should be directed towards fighting climate change and fair climate transition, the highest share ever of the European budget.

We could only compare Africa and Europe, as they have a similar N (34 and 36, respectively); the differences among the other geographical regions do not allow for such a comparison.

To determine whether there is a statistically significant association between changes in funding and some other variables, we performed a chi-squares test and a Fisher test applied to four variables separately. The first test, applied to the variables 'changes in funding' and 'researcher's continent', showed that there is an association between these two variables, with a p-value of 0.024 in the Fisher's test. The rest of the variables - funding agency, professional field, and research orientation - did not show an association with changes in funding, since all their $\mathrm{p}$ values were above 0.05 . 
To further explore this significant relationship between the geographical region or continent of the researcher and changes in financing, we decided to perform a MANOVA (multiple analysis of variance), which not only shows us this association but also shows us if there is a dependency between these and other variables.

To calculate the MANOVA, the geographic region (continent) was selected as the independent variable, and the following as dependent variables:

- Monthly income: divided into 7 categories (Low, Low middle, Middle, Upper Middle, Upper Middle, Low high, High, Upper high).

- Changes in financing: two categories (increase and decrease)

- Percentage of change in financing: 8 categories (more than $30 \%$ less, between $20-30 \%$ less, between $10-20 \%$ less, up to $10 \%$ less, up to $10 \%$ more, between $10-20 \%$ more, between $20-30 \%$ more and more than $30 \%$ more).

The results are shown below in Table 3 , highlighting the p-value of 0.001 , which indicates that there is a dependence of the last three variables mentioned with the geographical region of the respondent.

Table 3

Results of MANOVA

\begin{tabular}{|l|l|}
\hline Lambda & 0.507 \\
\hline F (Observed values) & 2.681 \\
\hline GL1 & 15 \\
\hline GL2 & 144 \\
\hline F (Critical value) & 1.736 \\
\hline p-value & 0.001 \\
\hline * The risk of rejecting the null hypothesis H0 (variables are independent) & when true is less than $0.13 \%$. \\
\hline
\end{tabular}

\subsection{Interpretation of the results of the bibliometric analysis}

The bibliometric analysis shows that connections between COVID-19 and poverty have been, relatively, more discussed than those between COVID-19 and climate change. The red color in the map is more related to impacts discussed in the context of poverty. It may indicate that the pandemic and associated response measures such as lockdowns have exacerbated poverty and significantly affected livelihood capacities, food security, and mental health of some societal groups. This is in line with arguments in the literature that some groups are disproportionately affected by the pandemic (51). In terms of connections between COVID-19 and climate change, it is evident that implications for both mitigation and adaptation are discussed in the literature. Most notably, the pandemic resulted in temporary reductions in global GHG emissions due to strict lockdown measures (52). Also, given its major impacts on the global economy, it has been discussed that the pandemic will have major implications for climate change adaptation and mitigation efforts. This, in particular, has been discussed about economic consequences such as poverty and unemployment. Increased unemployment will further reduce the adaptive capacity of citizens and increase poverty. This may direct the existing governmental budget towards poverty alleviation and reduce the budget needed to implement climate actions, thereby making it difficult to implement mitigation measures such as carbon pricing, which puts more pressure on the urban poor (26). The 
stimulus packages designed for economic recovery may also delay actions aimed at achieving climate stabilization targets.

Accordingly, recovery packages should be designed and implemented in a way whereby economic growth and emissions are decoupled (24). Furthermore, enhancing adaptation and mitigation prospects requires overcoming the socio-economic inequalities that are further deepened by the pandemic. Indeed, climate change disproportionately affects the poor and vulnerable groups; therefore, reducing inequalities should improve citizen adaptive capacities (26). Additionally, it can contribute to mitigation, as citizens are believed to better support mitigation policies that they perceive as fair (26). For instance, fair policies that ensure meeting the needs of poor communities contribute to mitigation by protecting the natural ecosystems and forests (as major carbon sinks) that would otherwise be cut down by poor rural households to meet their livelihood needs. To ensure a green economic recovery that contributes to climate change adaptation and mitigation, it is critical to scale up the investment in clean infrastructure and renewable energy technologies, increase investment in ecosystem protection and restoration, enhance infrastructure efficiency, and take actions towards minimizing COVID-19-induced poverty through capacity building, training, and education programs aimed at reducing unemployment (24).

The reviewed literature has also emphasized that climate change should be addressed with the same urgency as the pandemic, and it has drawn similarities between climate change and the pandemic in the sense that both affect vulnerable and poor groups disproportionately.

Both COVID-19 and climate change are argued to be major health threats that are closely linked and can have intensifying effects on each other $(53,54)$. If not designed appropriately, actions aimed at dealing with both pandemics and climate change may exacerbate inequalities. For instance, lockdown measures in the absence of financial support will impact the livelihood capacities of underprivileged groups; similarly, some climate change measures such as carbon pricing affect low-income people disproportionately (51). Accordingly, government recovery stimulus plans should ensure fair and equitable distribution of resources. This way, the economic distress associated with unemployment will be minimized. As a consequence, individuals are more likely to care about climate issues and perceive them as risks (51).

In the term co-occurrence Fig. 5, the term health also has a central place and is closely linked to other terms such as disparity, equity, poverty, and climate change. This is indicative of the significance of carefully designed health measures, such as universal health coverage for better preparation and response to pandemics as well as climate change impacts. Affordable health coverage ensures universal access to preventive as well as therapeutic healthcare and is essential for dealing with COVID-19 as well as climate-induced risks (55). Overall, overcoming poverty and reducing inequalities are believed to be key determinants of the success of climate policies as well as pandemic response measures.

\section{Conclusions}

This study employed a mixed-methods approach to shed light on some preliminary findings on the pandemic's implications for poverty and climate change adaptation efforts, as a result of switching priorities and funding. Utilizing a questionnaire-based survey to gather expert opinion, we attempted to examine whether priorities for climate change initiatives and projects have decreased as a result of the COVID-19 pandemic. The survey results 
were complemented by a bibliometric analysis to gain an overview of the knowledge structure on the interactions amongst the COVID-19 pandemic, climate change policies, and poverty.

It is relevant to note that $77.8 \%$ of the respondents point out that the COVID-19 pandemic is of particular relevance for their ongoing research, and $56 \%$ confirm that the impact of the pandemic crisis on their climate change research agenda will increase in the coming years. Findings also indicate a perceived decrease in funding since the pandemic crisis began for $29 \%$ of the respondents, while the funding for $33.3 \%$ was stopped or postponed by their respective funding agencies. This is most evident among climate change researchers in Africa, where $41 \%$ report a decrease in project funding. Our findings suggest an association between the region, the researchers who are based in and changes in funding, but this warrants further attention and investigation.

The bibliometric analysis reveals that a greater emphasis has been placed on the relationship between COVID-19 and poverty when compared to the interrelations between COVID-19 and climate change. The term co-occurrence analysis suggests that the term 'health' has a central place and is closely linked to terms such as 'disparity', 'equity', 'poverty' as well as 'climate change'. In terms of connections between COVID-19 and climate change, implications for both mitigation and adaptation are examined in the literature. The reviewed literature stresses that addressing climate change is as urgent as the pandemic crisis and that both affect the most vulnerable and poor social groups disproportionately. Likewise, both COVID-19 and climate change are defined as major health threats that are closely interrelated and may have aggravating effects on each other.

The merits of the work reside in the fact that it is one of the few papers which has examined the negative impacts of the COVID-19 pandemic on climate change research, especially in respect of the availability of funding. Also, the data from 49 countries suggest that this is a global trend, as opposed to a regional one.

This paper has some limitations. Firstly, the sample is limited to allow detailed lessons to be taken. Secondly, the promotion of the study was mostly among climate researchers who have access to electronic networks, so many were not aware of the study, despite our effort to spread it better. The limited duration of the survey also means that the time available for data collection was rather limited.

Despite these constraints, the inputs provided by 103 respondents from 49 countries allow a rough profile to be built, on the impacts of the pandemic on the priorities seen in many nations. This is a welcome addition to the literature since the pandemic is known to have influenced climate change initiatives in a significant way.

The twin crisis of the COVID-19 pandemic, i.e., an economic as well as a health crisis (among many other impacts), has presented mankind with many challenges and has called into question overarching assumptions regarding the achievement of global wellbeing and environmental sustainability. Figure 6 outlines three possible scenarios:

Scenario 1: funding to climate change is reduced, further inhibiting efforts to tackle it.

Scenario 2: funding cuts are stopped and levels of funding are levelled up.

Scenario 3: Funding to support climate change initiatives increase

It is at the moment unclear which scenario is more realistic. Scenario 3 is only realistic if the world economy recovers rather quickly, and the pandemic is fully under control.

In this respect, redefining climate actions under the scope of SDG 13 may provide meaningful insights towards a climate-proof and low-carbon economy in the long term. Whereas the steep drop of global production and consumer 
demand seen during the earlier stages of the COVID-19 pandemic may have bought us a little time, there is an urgent need for well-aimed responses and to step up efforts in order to prevent the potential of the pandemic to undermine the achievement of the SDGs (especially SDG 13) worldwide. No country or region should be left behind. Whilst the high risk of retreating/rebounding to a business-as-usual normality is evident, policy responses need to drive climate change mitigation and adaptation away from uncoordinated priorities, and towards specific and targets, using adequate indicators. This is particularly important, as the feasibility of achieving the overall SDGs agenda by 2030 has been put into doubt due to the pandemic. Still, the new circumstances around human-planetary systems especially health- encapsulate new opportunities to build on the work already achieved and recalibrate the drive for sustainability in a post-COVID-19 context.

To this end, further inter-and trans-disciplinary cooperation on climate mitigation and adaptation is needed, to pave the way for the measures which are now being implemented, as the world tries to recover from the pandemic. The importance of climate action cannot be underestimated or ignored, as further inertia may exacerbate the current COVID-19 impacts and could undermine long-term development prospects.

\section{List Of Abbreviations}

COVID-19 - Coronavirus disease

CC - climate change

SARS-CoV-2 - severe acute respiratory syndrome coronavirus 2

$\mathrm{GHG}=$ Greenhouse gas

GDP - Gross domestic product

IMF - International Monetary fund

SMEs-Small and medium enterprises

OECD - Organization for Economic Co-operation and Development

IPCC - Intergovernmental Panel on Climate Change

IEA - International Energy Agency

GSI - Greenness of Stimulus Index

IISD - International Institute for Sustainable Development

SDG: Sustainable development goal

VOS - Visualizing scientific landscapes

MANOVA - multiple analysis of variance

\section{Declarations}




\section{Ethics approval and consent to participate}

Not applicable.

\section{Consent for publication}

Not applicable.

\section{Availability of data and materials}

Not applicable.

\section{Competing interest}

The authors declare that they have no known competing financial interests or personal relationships that could have appeared to influence the work reported in this paper.

\section{Funding}

This research was performed by the European School of Sustainability Science and Research (ESSSR). It did not receive any specific grant from funding agencies from the public, commercial, or not-for-profit sectors.

\section{Authors' Contribution}

Walter Leal: Conceptualization, Writing, Supervision; Aprajita Minhas: Methodology, Investigation, Writing; Birgit Schmook: Methodology, formal analysis, Writing; Sofia Mardero: Methodology, formal analysis, Writing; Ayyoob Sharifi: Methodology, formal analysis, Investigation, Writing; Shlomit Paz: Methodology, Writing, Investigation; Marina Kovaleva: Writing; Maria Cristina Albertini: Writing; Antonis Skouloudis: Writing.

\section{Acknowledgements}

Not applicable

\section{References}

1. COVID-19, World Meter, 2021. Available from: https://www.worldometers.info/coronavirus/? utm_campaign=homeAdvegas1 (accessed 27.02.2021)

2. Yuki, K., Fujiogi, M., Koutsogiannaki, S., 2020. COVID-19 pathophysiology: A review. Clin Immunol 215, 108427. https://doi.org/10.1016/j.clim.2020.108427

3. Caristia, S., Ferranti, M., Skrami, E., Raffetti, E., Pierannunzio, D., Palladino, R., Carle, F., Saracci, R., Badaloni, C., Barone-Adesi, F., Belleudi, V., Ancona, C., AIE working group on the evaluation of the effectiveness of lockdowns, 
2020. Effect of national and local lockdowns on the control of COVID-19 pandemic: a rapid review. Epidemiol Prev 44, 60-68. https://doi.org/10.19191/EP20.5-6.S2.104

4. Forster, P.M., Forster, H.I., Evans, M.J., Gidden, M.J., Jones, C.D., Keller, C.A., Lamboll, R.D., Quéré, C.L., Rogelj, J., Rosen, D., Schleussner, C.-F., Richardson, T.B., Smith, C.J., Turnock, S.T., 2020. Current and future global climate impacts resulting from COVID-19. Nat. Clim. Chang. 10, 913-919. https://doi.org/10.1038/s41558-020-0883-0

5. Manzanedo, R.D., Manning, P., 2020. COVID-19: Lessons for the climate change emergency. Sci Total Environ 742, 140563. https://doi.org/10.1016/j.scitotenv.2020.140563

6. Gautam, A.S., Pathak, N., Ahamad, T., Semwal, P., Bourai, A.A., Rana, A.S., Nautiyal, O.P., 2021. Pandemic in India: Special reference to Covid-19 and its technological aspect. Journal of Statistics and Management Systems 24, 387-410. https://doi.org/10.1080/09720510.2021.1879469

7. Štreimikienè, D., Baležentis, T., Volkov, A., Ribašauskienè, E., Morkūnas, M., Žičkienè, A., 2021. Negative effects of covid-19 pandemic on agriculture: systematic literature review in the frameworks of vulnerability, resilience and risks involved. Economic Research-Ekonomska Istraživanja 0, 1-17.

https://doi.org/10.1080/1331677X.2021.1919542

8. Nicola, M., Alsafi, Z., Sohrabi, C., Kerwan, A., Al-Jabir, A., losifidis, C., Agha, M., Agha, R., 2020. The socioeconomic implications of the coronavirus pandemic (COVID-19): A review. Int J Surg 78, 185-193. https://doi.org/10.1016/j.ijsu.2020.04.018

9. Barnett, M. L., Mehrotra, A., \& Landon, B. E. 2020. Covid-19 and the upcoming financial crisis in health care. NEJM Catalyst Innovations in Care Delivery, 1(2). doi: http://doi.org/10.1056/CAT.20.0153

10. Bashir, M. F., Benjiang, M., \& Shahzad, L. 2020. A brief review of the socio-economic and environmental impact of Covid-19. Air Quality, Atmosphere \& Health, 13(12), 1403-1409. doi: https://doi.org/10.1007/s11869-02000894-8

11. Sahu, P. 2020. Closure of universities due to coronavirus disease 2019 (COVID-19): impact on education and mental health of students and academic staff. Cureus, 12(4). doi: http://doi.org/10.7759/cureus.7541

12. Bousema, T., Selvaraj, P., Djimde, A. A., Yakar, D., Hagedorn, B., Pratt, A.,.. . Cohen, J. M. (2020). Reducing the carbon footprint of academic conferences: the example of the American Society of Tropical Medicine and Hygiene. The American Journal of Tropical Medicine and Hygiene, 103(5), 1758-1761. doi:

https://doi.org/10.4269/ajtmh.20-1013

13. lacus, S. M., Natale, F., Santamaria, C., Spyratos, S., \& Vespe, M. 2020. Estimating and projecting air passenger traffic during the COVID-19 coronavirus outbreak and its socio-economic impact. Safety Science, 129, 104791 doi: https://doi.org/10.1016/j.ssci.2020.104791

14. Parolin, Z., \& Wimer, C. 2020. Forecasting estimates of poverty during the COVID-19 crisis. Poverty and Social Policy Brief. New York, NY: Center on Poverty and Social Policy at the Columbia School of Social Work, 4(6).

15. Wegerif, M. C. 2020. "Informal" food traders and food security: experiences from the Covid-19 response in South Africa. Food Security, 12(4), 797-800. doi: https://doi.org/10.1007/s12571-020-01078-z

16. Mimoun, E., Ben Ari, A., \& Margalit, D. 2020. Psychological aspects of employment instability during the COVID19 pandemic. Psychological Trauma: Theory, Research, Practice, and Policy, 12(S1), S183. doi: https://doi.org/10.1037/tra0000769

17. Pfefferbaum, B., \& North, C. S. 2020. Mental health and the Covid-19 pandemic. New England Journal of Medicine, 383(6), 510-512. doi: http://doi.org/10.1056/NEJMp2008017

18. Mittal, S., \& Singh, T. 2020. Gender-based violence during COVID-19 pandemic: a mini-review. Frontiers in Global Women's Health, 1, 4. doi: https://doi.org/10.3389/fgwh.2020.00004 
19. Fuentes, R., Galeotti, M., Lanza, A., Manzano, B. 2020. COVID-19 and Climate Change: A Tale of Two Global Problems. Sustainability, 12, 8560. https://doi.org/10.3390/su12208560

20. Volz, U. Investing in a green recovery, International Momentary fund, 2020. Available from: https://www.imf.org/external/pubs/ft/fandd/2020/09/investing-in-a-green-recovery-volz.htm (accessed 30.01.21).

21. Global Climate Change Alliance+, 2020. The effect of coronavirus on climate finance. Available from: https://www.gcca.eu/stories/effect-coronavirus-climate-finance (accessed 30.01.21).

22. IMF (International Monetary Fund) 2020. World Economic Outlook update, June 2020. Available from: https://www.imf.org/en/Publications/WEO/Issues/2020/06/24/WEOUpdateJune2020 (accessed 31.01.2021)

23. European Commission, 2020. European Economic Forecast Spring 2020. Institutional Paper 125. https://ec.europa.eu/info/sites/info/files/economy-finance/ip125_en.pdf

24. Hepburn, Cameron O'Callaghan, Brian, Stern, Nicholas, Stiglitz, Joseph, Zenghelis, Dimitri 2020. Will COVID-19 fiscal recovery packages accelerate or retard progress on climate change? Oxford Review of Economic Policy, Volume 36, Issue Supplement_1, 2020, Pages S359-S381, https://doi.org/10.1093/oxrep/graa015

25. Gawel, E. and Lehmann, P. 2020. Killing Two Birds with One Stone? Green Dead Ends and Ways Out of the COVID-19 Crisis. In: Perspectives on the Economics of the Environment in the Shadow of Coronavirus. Environ Resource Econ 76, 447-517. https://doi.org/10.1007/s10640-020-00493-2

26. Klenert, D., Funke, F., Mattauch, L. et al. Five Lessons from COVID-19 for Advancing Climate Change Mitigation. Environ Resource Econ 76, 751-778 (2020). https://doi.org/10.1007/s10640-020-00453-w

27. Quevedo. A, Peters. K, and Cao. Y, The impacts of COVID-19 on climate change and disaster resilience funding, Flood resilience alliance, 2020. Available from: https://www.odi.org/sites/odi.org.uk/files/resourcedocuments/covid_and_resilience_funding_briefing_note_web_0.pdf (accessed 30.01.2021)

28. Green Climate Fund, 2020. Tipping or turning point: Scaling up climate finance in the era of COVID-19. Green Climate Fund. Available from: https://www.greenclimate.fund/document/tipping-or-turning-point-scalingclimate-finance-era-covid-19 (accessed 31.1.21).

29. OECD 2020. Provided and Mobilised by Developed Countries in 2013-18. OECD Publishing, Paris, https://doi.org/10.1787/f0773d55-en

30. IPCC, 2018. Summary for Policymakers. In: Global warming of $1.5^{\circ} \mathrm{C}$. An IPCC Special Report on the impacts of global warming of $1.5^{\circ} \mathrm{C}$ above pre-industrial levels and related global greenhouse gas emission pathways, in the context of strengthening the global response to the threat of climate change, sustainable development, and efforts to eradicate poverty. Available from: https://www.ipcc.ch/sr15/ (accessed. 02.02.2021)

31. Morgan Stanley 2019. Decarbonization: The Race to Net-Zero. Sustainability. BluePaper. https://www.morganstanley.com/ideas/investing-in-decarbonization (accessed 02.02.2021)

32. CPI 2019. Global Landscape of Climate Finance 2019 - Methodology. Available from: https://www.climatepolicyinitiative.org/wp-content/uploads/2019/11/GLCF-2019-Methodology-Document.pdf

33. Macquarie, R., Naran, B., Rosane, P., Solomon, M., Wetherbee, C., Buchner, B. 2020. Updated View on the Global Landscape of Climate Finance 2019. Available from:

https://www.climatepolicyinitiative.org/publication/updated-view-on-the-global-landscape-of-climate-finance2019/

34. Buchner, B., Clark, A., Falconer, A., Macquarie, R., Meattle, C., Tolentino, R., Wetherbee, C. 2019. Global Landscape of Climate Finance 2019. A CPI Report. Climate Policy Initiative, London. Available from:

https://www.climatepolicyinitiative.org/publication/global-landscape-of-climate-finance-2019/

Page $17 / 23$ 
35. UNEP 2021. Adaptation Gap Report 2020. United Nations Environment Programme (UNEP) Nairobi. Available from: https://www.unep.org/resources/adaptation-gap-report-2021

36. Gosens, J. and Jotzo, F. 2020. China's post-COVID-19 stimulus: No Green New Deal insight. Environmental Innovation and Societal Transitions, Volume 36, pp. 250-254. https://doi.org/10.1016/j.eist.2020.07.004

37. IEA, 2020. World Energy Investment 2020. Flagship report 2020. International Energy Agency (IEA). Paris. Available from: https://www.iea.org/reports/world-energy-investment-2020

38. Vivid Economics 2020. Greenness of Stimulus Index Report. Finance for Biodiversity Initiative (F4B). https://www.vivideconomics.com/wp-content/uploads/2021/01/201214-GSI-report_December-release.pdf

39. Barbier, E.B. 2020. Greening the Post-pandemic Recovery in the G20. Environ Resource Econ 76, 685-703. https://doi.org/10.1007/s10640-020-00437-w

40. European Commission, 2021. Recovery plan for Europe. Available from: https://ec.europa.eu/info/strategy/recovery-planeurope_en\#: :text=The\%20largest\%20stimulus\%20package\%20ever,The\%20EU's\%20long\&text=A\%20total\%20of\%20\%E2\%82\%AC1.8,digital\%20and\%20more\%20resilient\%20Europe (accessed 02.02.2021)

41. National People's Congress, 2020. 2020 Government Work Report (In English). Available from: http://english.www.gov.cn/premier/news/202005/30/content_WS5ed197f3c6d0b3f0e94990da.html (accessed 02.02.2021).

42. KPMG, 2020. Russia. Government and institution measures in response to COVID-19. Available from: https://home.kpmg/xx/en/home/insights/2020/04/russia-government-and-institution-measures-in-response-tocovid.html (accessed 02.02.2021)

43. Ostapets, I, Dmitrieva, I, Zagonek, J, Lapshin, D, and Nikitina, N. 2020. COVID-19: Russian Legal Impact. Available from: https://www.whitecase.com/sites/default/files/2020-03/COVID-19-russian-legal-update-eng.pdf

44. World Resource Institute, 2020. Statement: Congress Passes Major Stimulus Package with Significant Provisions for Climate Change. Available from: https://www.wri.org/news/2020/12/statement-congresspasses-major-stimulus-package-significant-provisions-climate-change (accessed 02.02.2021).

45. CARES Act (Coronavirus Aid, Relief, and Economic Security Act) H.R.748- CARES Act. 2020. Public Law No: 116-136. Available from: https://www.congress.gov/bill/116th-congress/house-bill/748

46. Tashiro, A. and Shaw, R. 2020. COVID-19 Pandemic Response in Japan: What Is behind the Initial Flattening of the Curve? Sustainability, 12(13), 5250; https://doi.org/10.3390/su12135250

47. IISD, 2020. Japan unveils USD 700 billion stimulus package. Available from: https://www.iisd.org/sustainablerecovery/news/japan-unveils-usd-700-billion-stimulus-package/ (accessed 02.02.2021)

48. Federal Ministry of Finance 2021. Emerging from the crisis with full strength. Available from: https://www.bundesfinanzministerium.de/Content/EN/Standardartikel/Topics/Public-Finances/Articles/202006-04-fiscal-package.html

49. Department of Finance Canada, 2020. Canada's COVID-19 Economic Response Plan: Support for Canadians and Businesses. Available from: https://www.canada.ca/en/department-finance/news/2020/03/canadascovid-19-economic-response-plan-support-for-canadians-and-businesses.html (accessed 02.02.2021)

50. van Eck, N.J., Waltman, L., 2010. Software survey: VOSviewer, a computer program for bibliometric mapping. Scientometrics 84, 523-538. https://doi.org/10.1007/s11192-009-0146-3 
51. Botzen, W., Duijndam, S., van Beukering, P., 2021. Lessons for climate policy from behavioral biases towards COVID-19 and climate change risks. World Dev 137, 105214. https://doi.org/10.1016/j.worlddev.2020.105214

52. Le Quéré, C., Jackson, R.B., Jones, M.W., Smith, A.J.P., Abernethy, S., Andrew, R.M., De-Gol, A.J., Willis, D.R., Shan, Y., Canadell, J.G., Friedlingstein, P., Creutzig, F., Peters, G.P., 2020. Temporary reduction in daily global CO2 emissions during the COVID-19 forced confinement. Nat. Clim. Chang. 10, 647-653.

https://doi.org/10.1038/s41558-020-0797-x

53. Leal Filho, W., Nagy, G., Ayal D. 2020 Climate Change, Health and Pandemics- a Wake-Up Call from COVID-19. International Journal of Climate Change Strategies and Management 12(4):533-535 17 Aug 2020 DOI https://www.emerald.com/insight/content/doi/10.1108/IJCCSM-08-2020-212/full/html

54. Negev, Maya, et al. 2021. "Regional Lessons from the COVID-19 Outbreak in the Middle East: From Infectious Diseases to Climate Change Adaptation." Science of The Total Environment 768: 144434. Available from: http://www.sciencedirect.com/science/article/pii/S0048969720379651.

55. Phillips, Carly A, et al. 2020. "Compound Climate Risks in the COVID-19 Pandemic." Nature Climate Change 10(7): 586-88. https://doi.org/10.1038/s41558-020-0804-2

\section{Figures}

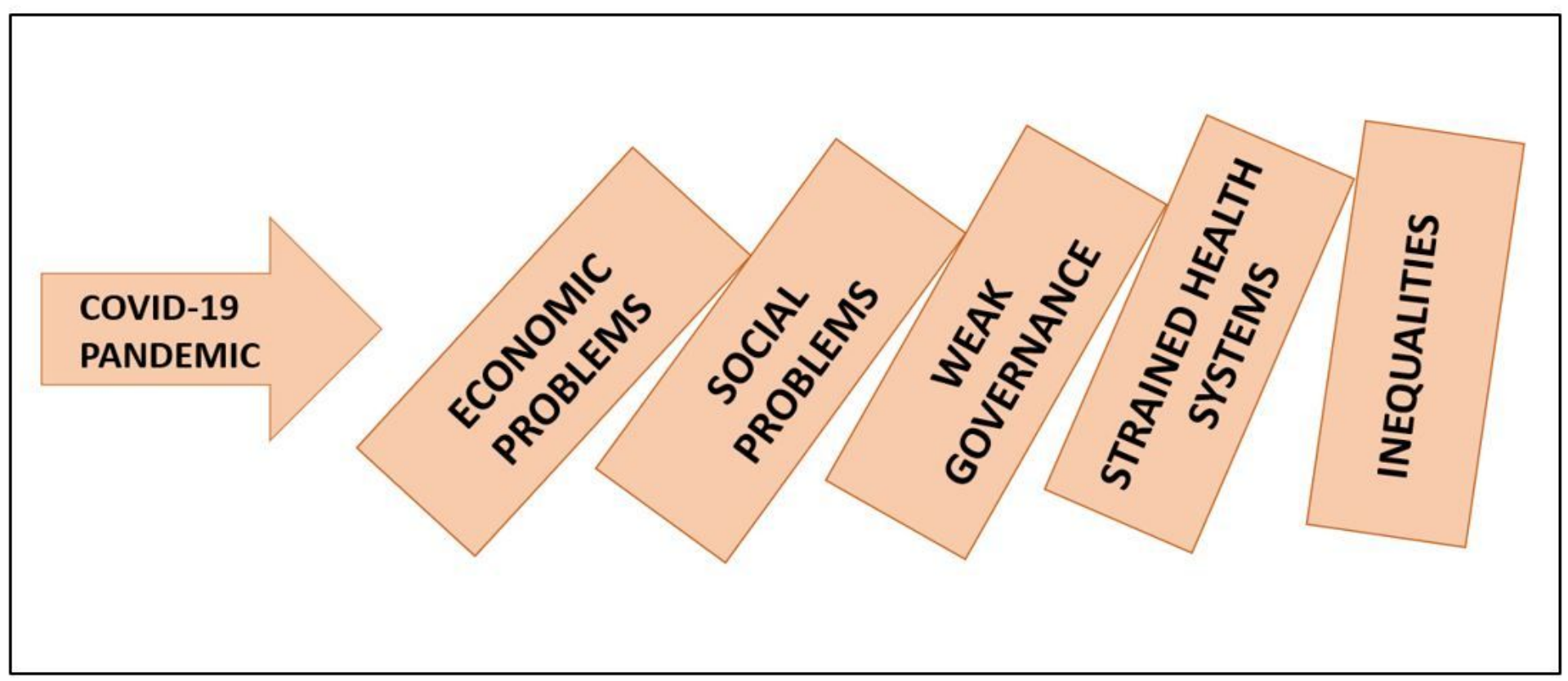

Figure 1

The domino effect of the COVID-19 pandemic 


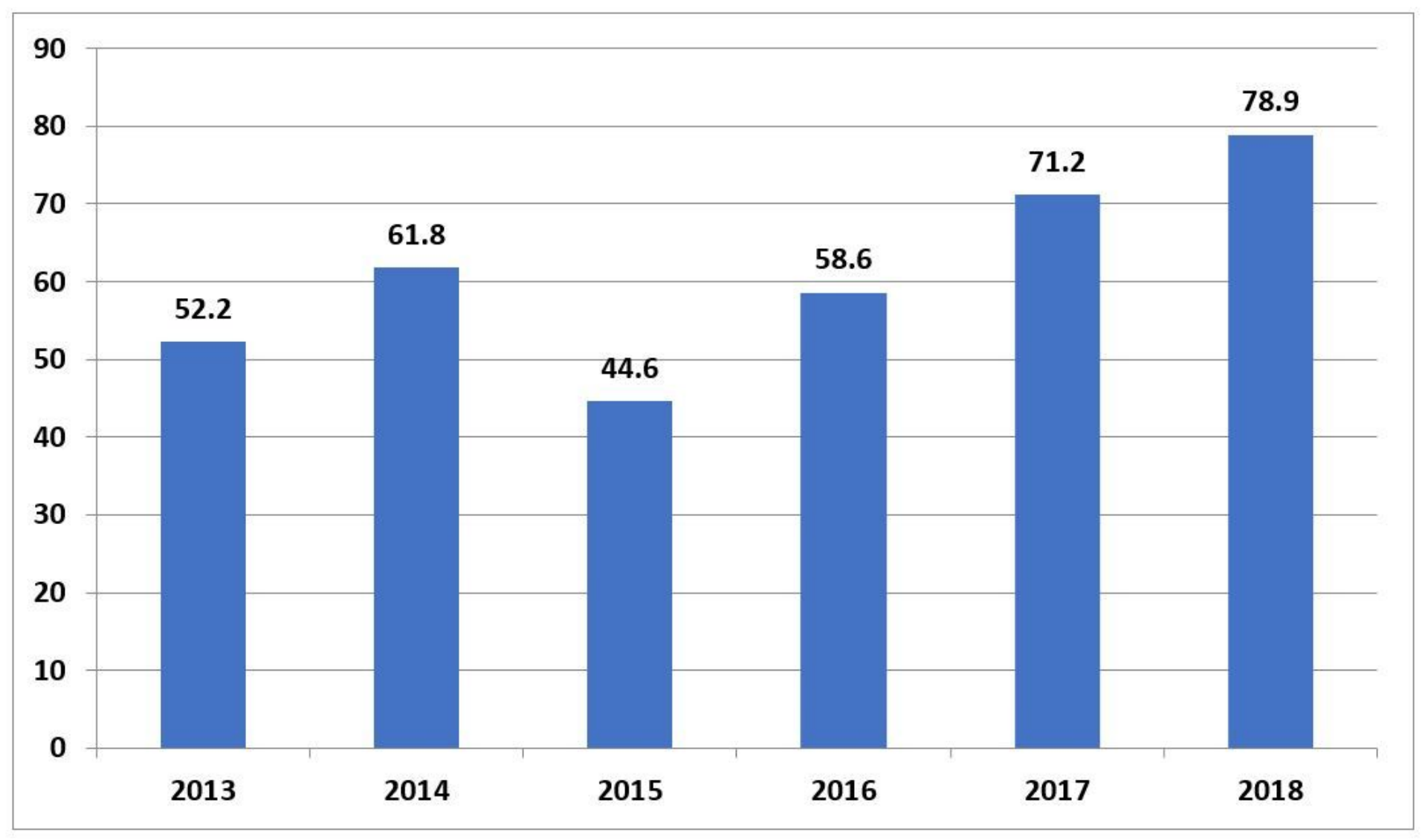

Figure 2

Public and private climate finance provided by the OECD nations between the years 2013 and 2018, USD billion. *Grand totals in 2013-14 and 2016-18 are not to be compared directly due to the lack of data on private finance in 2015 and enhanced accounting methods. (Source: OECD 2020 [29]) 


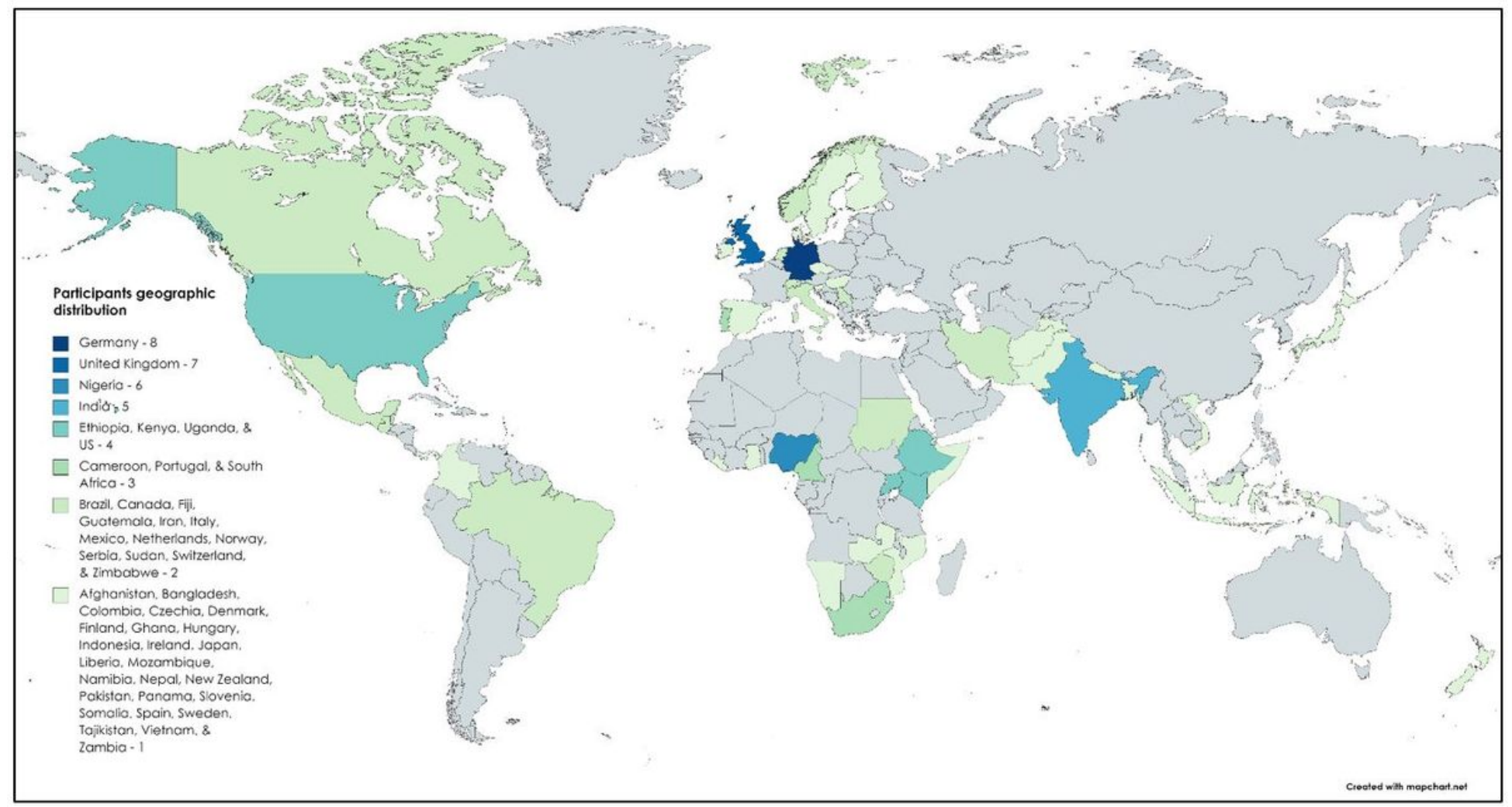

Figure 3

Shows the Geographic distribution of the participants

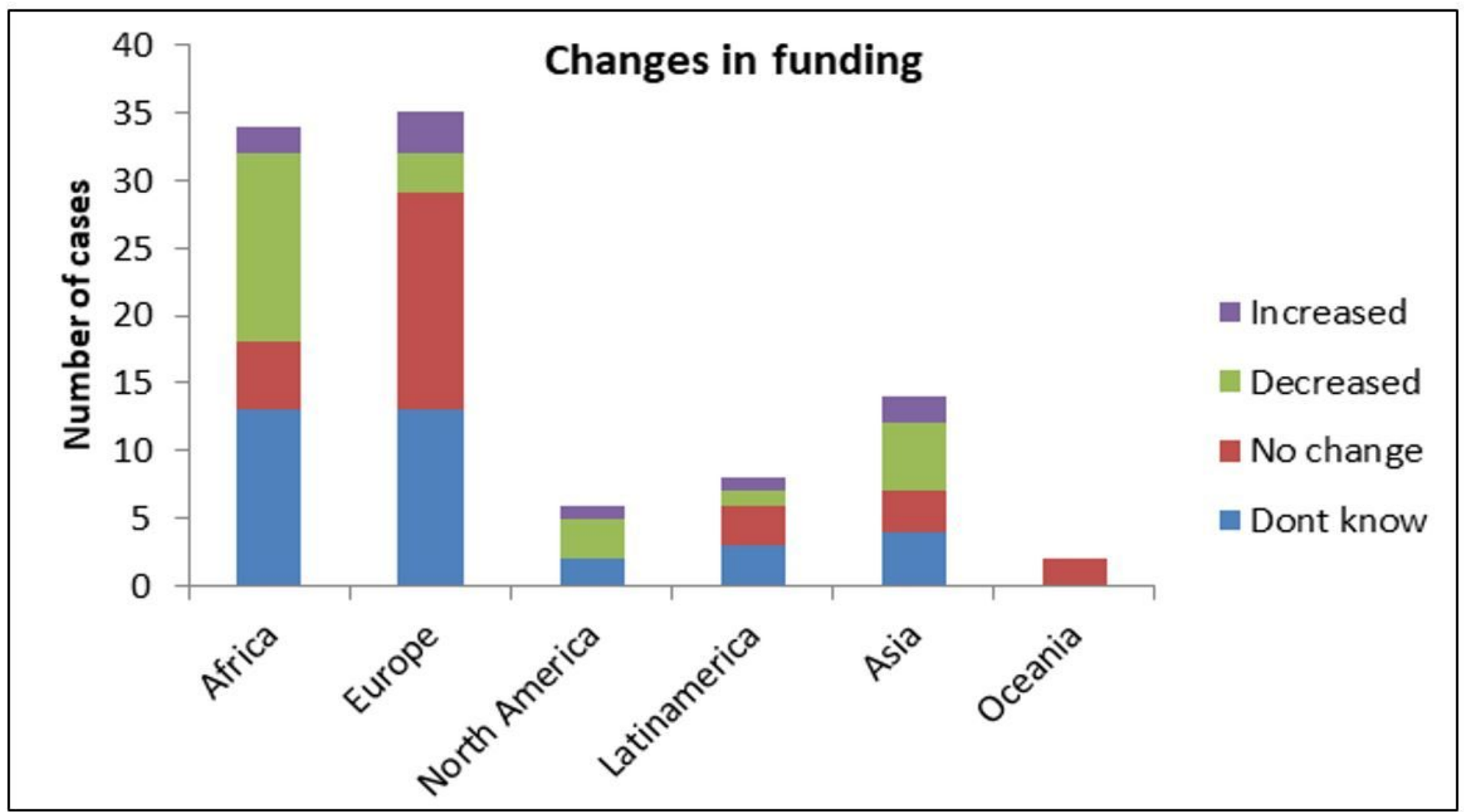

Figure 4 


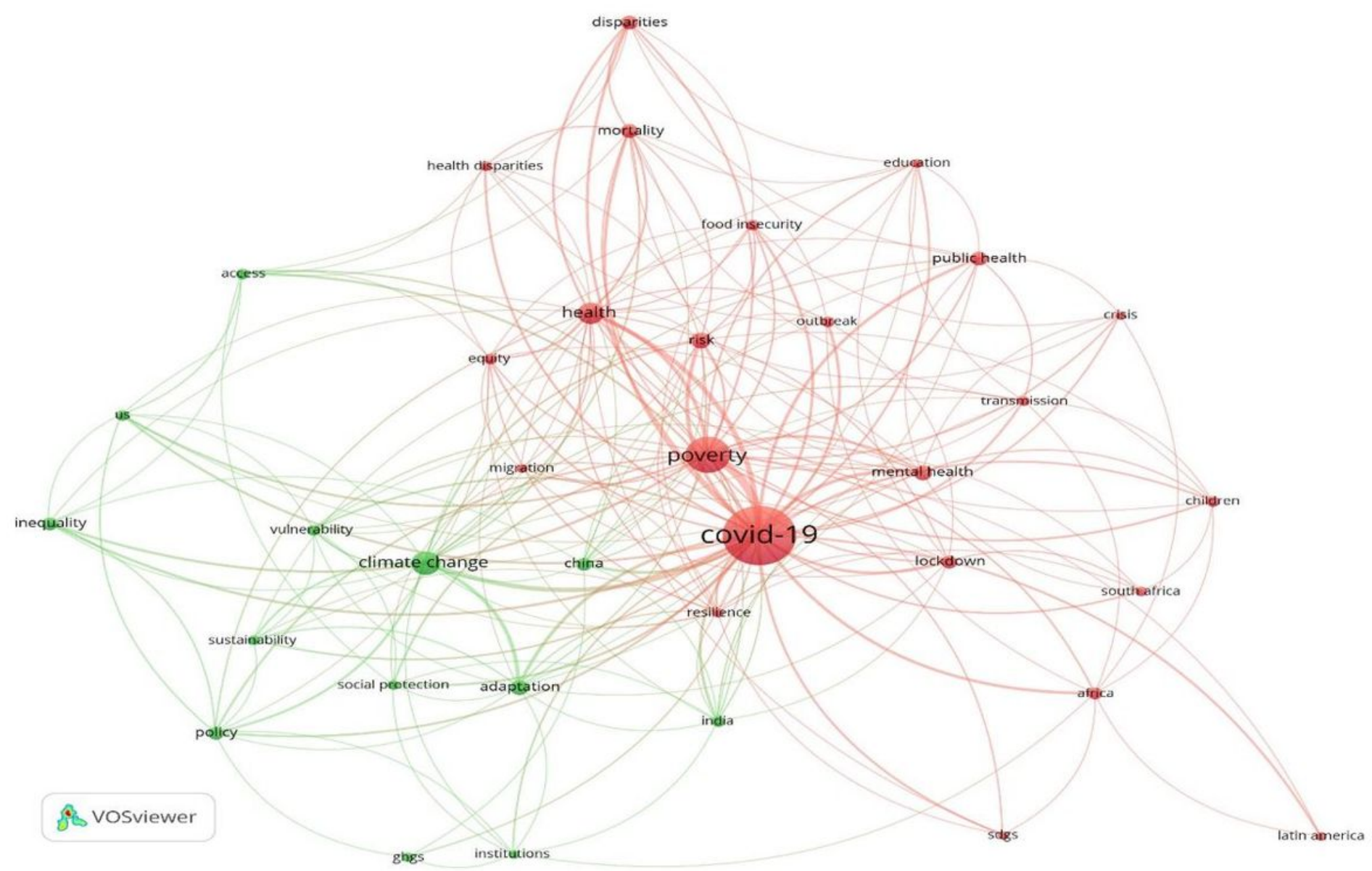

\section{Figure 5}

Result of the term co-occurrence analysis 


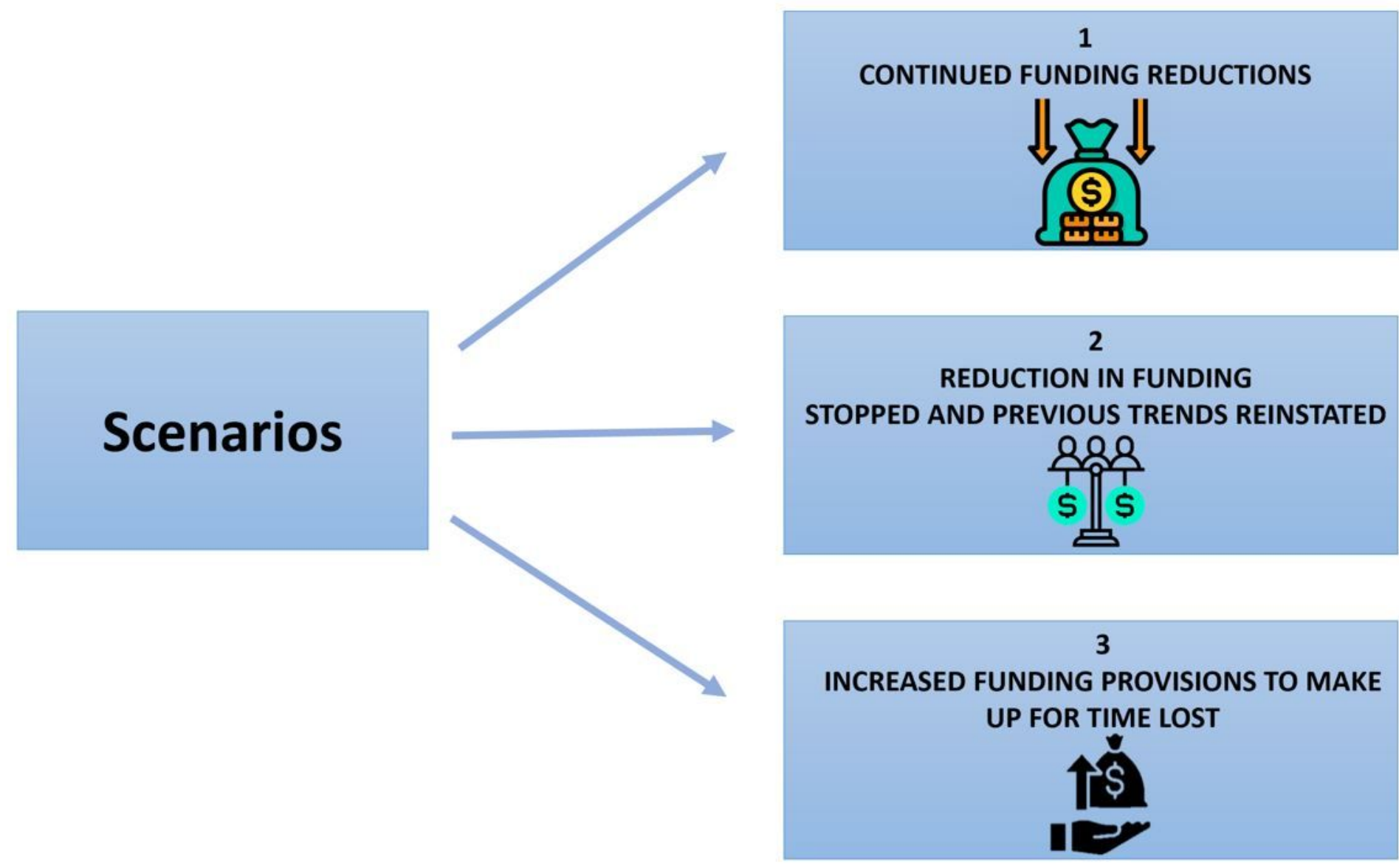

Figure 6

Possible Scenarios Associated with Funding to Climate Change in Connection with the Pandemic

\section{Supplementary Files}

This is a list of supplementary files associated with this preprint. Click to download.

- AppendixA.docx 